\title{
TINJAUAN TEORI PERUNDANG-UNDANGAN TERHADAP UNDANG-UNDANG NOMOR 11 TAHUN 2012 TENTANG SISTEM PERADILAN PIDANA ANAK
}

\author{
Afione Ade Rosika \\ Fakultas Hukum Universitas Ahmad Yani \\ afioneaderosika@gmail.com
}

\begin{abstract}
ABSTRAK
Teori Perundang-Undangan berorientasi pada mencari kejelasan, kejernihan makna atau pengertian dan bersifat kognitif. Artinya, Teori PerundangUndangan menekankan bukan pada proses pembentukan peraturan perundangUndangan, namun menekankan pada bagaimana membentuk materi Peraturan Perundang-Undangan. Dalam membentuk materi pada Undang-Undang Nomor 11 Tahun 2012 tentang Sistem Peradilan Pidana Anak harus berpedoman pada dasardasar dalam penyusunan Peraturan perundang-undangan dan memperhatikan tujuan dari Undang-Undang Sistem Peradilan Pidana Anak itu sendiri. Tujuan dibentuknya Undang-Undang Sistem Peradilan Pidana Anak adalah untuk dapat mewujudkan peradilan yang benar-benar menjamin perlindungan terbaik terhadap anak yang berhadapan dengan hukum.
\end{abstract}

Kata Kunci : Teori Perundang-Undangan, Sistem Peradilan Pidana Anak

\begin{abstract}
Legislation Theory is oriented towards seeking clarity, clarity of meaning or understanding and is cognitive. The Legislation Theory emphasizes not the process of establishing legislation, but emphasizes how to form the material of Legislation. In forming the material in Law Number 11 of 2012 concerning the Criminal Justice System the Child must be guided by the basics in drafting legislation and paying attention to the objectives of the Juvenile Justice System. The purpose of establishment The Juvenile Justice System is to be able to realize a judiciary that truly guarantees the best protection for children facing the law.
\end{abstract}

Keywords : Invitational Theory, The Juvenile Justice System

\section{A. PENDAHULUAN}

Hukum harus dapat menyesuaikan diri dengan perkembangan masyarakat dan mengatasi bentuk kejahatan apapun dengan penanganan hukum yang sesuai. Akan tetapi Indonesia sendiri belum mampu menyelaraskan ketiga komponen penting dalam hukum yaitu struktur hukum, budaya hukum dan substansi hukum. 
Berdasarkan pada bagaimana struktur hukumnya, Kinerja aparat penegak hukum sebagai bagian dari struktur suatu sistem peradilan pidana anak harus baik. Misalnya dalam pelaksanaan proses Penyidikan terhadap Anak yang Berkonflik dengan Hukum, harus sesuai dengan ketentuan dalam UU Nomor 11 Tahun 2012 Tentang Sistem Peradilan Pidana Anak. Anak yang Berkonflik dengan Hukum sebelum masuk pada proses penyidikan, harus diusahakan terlebih dahulu untuk dilakukan Diversi agar terhindar dari proses penahanan. Jadi, kinerja dari aparat penegak hukum sebagai bagian dari struktur hukum harus sesuai dengan ketentuan hukum yang ada.

Berdasarkan pada budaya hukumnya, budaya tidak mengulangi perbuatan melanggar hukum masih tinggi di masyarakat, termasuk Anak yang Berkonflik dengan Hukum. Anak yang berkonflik dengan Hukum masih sering melakukan pelanggaran hukum yang sama atau pelanggaran hukum lainnya. Masyarakat seharusnya memberikan kesempatan kepada anak melalui pembinaan agar menjadi manusia yang lebih bertanggung jawab bagi dirinya, keluarga, masyarakat dan negara. ${ }^{17}$.

Sedangkan berdasarkan pada substansi hukum, meskipun telah ada UU Nomor 11 Tahun 2012 tentang Sistem Peradilan Pidana Anak, namun dengan produk hukum yang telah sesuai dengan kebutuhan pun belum cukup, jika tidak diimbangi dengan komponen lain yang saling mendukung dan melengkapi. ${ }^{18}$ Untuk mengetahui apakah substansi hukum yaitu dalam hal ini adalah UU Nomor 11 Tahun 2012 tentang Sistem Peradilan Pidana Anak sudah baik ataukah belum, Penulis akan membahasnya dalam Jurnal Ilmiah ini dengan mengangkat judul "Tinjauan Teori Perundang-Undangan Terhadap UU Nomor 11 tahun 2012 Tentang Sistem Peradilan Pidana Anak"

Maka rumusan masalah yang timbul adalah sebagai berikut :

1. Jelaskan secara singkat mengenai Teori Perundang-Undangan?

2. Bagaimana tinjauan teori perundang-undangan terhadap UU Nomor 11 Tahun 2012 tentang Sistem Peradilan Pidana Anak?

\footnotetext{
${ }^{17} \mathrm{Ibid}, \mathrm{hlm} .102$

${ }^{18}$ Samin dan Yayasan Setara, Situasi Anak yang Berkonflik dengan Hukum, Yogyakarta : Samin dan Yayasan Setara, 2006, hlm.101
} 


\section{B. METODE PENELITIAN}

Metode pendekatan yang digunakan dalam penelitian ini adalah metode pendekatan yuridis normatif. Penelitian hukum yuridis normatif biasanya dianalisis secara deskriptif analitis. Sedangkan Spesifikasi penelitian dalam jurnal ini dilakukan secara deskriptif analitis.

Data yang digunakan dalam penelitian ini adalah data hukum sekunder. Data sekunder adalah data yang mendukung dan melengkapi data primer yang berhubungan dengan masalah penelitian. Data mencakup dokumen-dokumen resmi, buku-buku, hasil-hasil penelitian yang dapat berwujud laporan dan lainlainnya. Dalam penelitian ini, teknik untuk mengumpulkan data yang digunakan adalah dengan teknik Studi Pustaka dan dengan metode analisis data kualitatif.

\section{HASIL DAN PEMBAHASAN}

\section{A. TENTANG TEORI PERUNDANG-UNDANGAN}

Banyak orang sulit untuk membedakan antara apa itu Teori Perundangundangan dan apa itu Ilmu Perundang-Undangan. Beda antara Teori PerundangUndangan dan Ilmu Perundang-Undangan terletak pada orientasi substansinya. Teori Perundang-Undangan berorientasi pada mencari kejelasan dan kejernihan makna atau pengertian dan bersifat kognitif.

Teori Perundang-Undangan menekankan bukan pada proses pembentukan peraturan perundang-Undangan, namun menekankan pada bagaimana membentuk materi Peraturan perundang-undangan. Sedangkan Ilmu Perundang-Undangan berorientasi pada proses pembentukan peraturan perundang-Undangan.

Peraturan Perundang-Undangan itu sendiri adalah peraturan tertulis yang memuat norma hukum yang mengikat secara umum dan dibentuk atau ditetapkan oleh lembaga negara atau pejabat yang berwenang melalui prosedur yang ditetapkan dalam peraturan perundang-undangan. Teori Perundang-Undangan maupun Ilmu Perundang-Undangan dapat mengacu pada ketentuan UU Nomor 12 Tahun 2011 Tentang Pembentukan Peraturan Perundang-Undangan. 
UU Nomor 12 Tahun 2011 Tentang Pembentukan Peraturan PerundangUndangan didasarkan pada pemikiran bahwa Negara Indonesia adalah Negara Hukum. Sebagai Negara Hukum, segala aspek kehidupan dalam bidang kemasyarakatan, kebangsaan dan kenegaraan termasuk pemerintahan harus berdasarkan atas hukum yang sesuai dengan sistem hukum nasional. Sistem hukum nasional merupakan hukum yang berlaku di Indonesia dengan semua elemennya yang saling menunjang satu dengan yang lain dalam rangka mengantisipasi dan mengatasi permasalahan yang timbul dalam kehidupan bermasyarakat, berbangsa dan bernegara Pancasila dan UUD 1945

Selain itu, secara umum UU Nomor 12 Tahun 2011 Tentang Pembentukan Peraturan Perundang-Undangan ini memuat materi-materi pokok yang disusun secara sistematis yaitu:

1. Asas pembentukan Peraturan Perundang-Undangan;

2. Jenis, hierarki dan materi muatan Perundang-Undangan;

3. Materi muatan Peraturan Perundang-Undangan;

4. Perencanaan Peraturan Perundang-Undangan;

5. Penyusunan Peraturan Perundang-Undangan;

6. Teknik penyusunan Peraturan Perundang-Undangan;

7. Pembahasan dan pengesahan Rancangan Undang-Undang;

8. Pembahasan dan penetapan Rancangan Peraturan Daerah Provinsi dan Rancangan Peraturan Daerah Kabupaten atau Kota;

9. Pengundangan Peraturan Perundang-Undangan;

10. Penyebarluasan;

11. Partisipasi masyarakat dalam Pembentukan Peraturan PerundangUndangan;

12. Ketentuan lain yang memuat mengenai pembentukan Keputusan Presiden dan Lembaga Negara serta Pemerintah lainnya.

Dalam uraian tersebut diatas, kita akan menemukan mana yang menjadi bagian dari Teori Perundang-Undangan, yaitu dasar-dasar dalam Penyusunan 
Peraturan Perundang-Undangan. Dasar-dasar dalam Penyusunan Peraturan Perundang-Undangan tersebut antara lain :

1. Asas-asas pembentukan Peraturan Perundang-Undangan;

Asas pembentukan Peraturan Perundang-Undangan telah diatur di dalam Pasal 5 UU Nomor 12 Tahun 2011 Tentang Pembentukan Peraturan Perundang-Undangan.

2. Kewenangan Pembentuk Peraturan Perundang-Undangan;

Mengenai kewenangan pembentukan Peraturan PerundangUndangan, perlu diketahui bahwa kewenangan pembentukan UndangUndang berada di tangan DPR yang bersama dengan Presiden membahas dan menyetujui setiap Rancangan Undang-Undang. Selanjutnya Presiden mengesahkan RUU yang telah mendapat persetujuan bersama menjadi Undang-Undang. Pembuatan Undang-undang pada hakikatnya merupakan kekuasaan bersama antara DPR dan Presiden. Sementara kewenangan pembentukan Peraturan Perundang-Undangan yang tingkatannya di bawah Undang-Undang merupakan kewenangan Presiden, Kepala Daerah, atau Pimpinan Kementerian atau Lembaga sesuai kewenangannya.

3. Jenis dan Hierarki Peraturan Perundang-Undangan;

Jenis dan Hierarki Peraturan Perundang-Undangan ini telah diatur dalam Ketentuan Pasal 7 UU Nomor 12 Tahun 2011 Tentang Pembentukan Peraturan Perundang-Undangan.

4. Materi muatan Peraturan Perundang-Undangan.

Materi muatan Peraturan Perundang-Undangan telah diatur dalam ketentuan Pasal 10 UU Nomor 12 Tahun 2011 Tentang Pembentukan Peraturan Perundang-Undangan. Setiap jenis Peraturan PerundangUndangan dalam hierarki Peraturan Perundang-Undangan memiliki materi muatan masing-masing sesuai dengan porsinya. 


\section{B. TINJAUAN TEORI PERUNDANG-UNDANGAN TERHADAP UNDANG-UNDANG NOMOR 11 TAHUN 2012 TENTANG SISTEM PERADILAN PIDANA ANAK}

Teori Perundang-Undangan berorientasi pada mencari kejelasan dan kejernihan makna atau pengertian dan bersifat kognitif. Dalam hal ini maksudnya adalah Teori Perundang-Undangan menekankan bukan pada proses pembentukan peraturan Perundang-Undangan, namun menekankan pada bagaimana membentuk materi Peraturan perundang-undangan. Tinjauan Teori Perundang-Undangan terhadap UU Nomor 11 Tahun 2012 tentang Sistem Peradilan Pidana Anak berarti dapat diartikan meninjau dari segi hal-hal berikut ini :

1. Asas-asas pembentukan Peraturan Perundang-Undangan;

Asas pembentukan Peraturan Perundang-Undangan diatur dalam Pasal 5 UU Nomor 12 Tahun 2011 Tentang Pembentukan Peraturan PerundangUndangan, antara lain :

a. Asas Kejelasan Tujuan

Dibentuknya UU Nomor 11 Tahun 2012 Tentang Sistem Peradilan Pidana Anak memiliki tujuan yang jelas yaitu untuk mewujudkan Peradilan yang benarbenar menjamin perlindungan kepentingan terbaik bagi Anak yang Berhadapan dengan Hukum sebagai generasi penerus bangsa. Hal ini disebabkan karena Undang-Undang terdahulu yaitu UU Nomor 3 Tahun 1997 tentang Pengadilan anak dalam pelaksanaannya Anak belum mendapat Perlindungan.

Sebagai contoh dalam proses Penyidikan, masih ada Anak yang harus menjalani penahanan dalam satu ruang tahanan yang sama dengan tahanan dewasa, meskipun Anak tersebut berada dalam sel tahanan yang berbeda. ${ }^{19}$ Dalam ketentuan Pasal 45 ayat (3) UU Nomor 3 Tahun 1997 Tentang Pengadilan Anak memang hanya mengatur bahwa Penahanan terhadap Anak Nakal dilakukan dalam sel tahanan yang berbeda dengan tahanan dewasa. Namun jika Anak ditahan dalam satu ruang tahanan yang sama dengan tahanan dewasa, meskipun Anak tersebut berada dalam sel tahanan yang berbeda, maka sama saja anak tidak

\footnotetext{
19 Penulisan Hukum tentang "Implementasi Hak-Hak Anak Sebagai Tersangka dalam proses Penyidikan Berdasarkan Undang-Undang Nomor 3 tahun 1997 Tentang Pengadilan Anak, atas nama Afione Ade Rosika, Tahun 2014
} 
mendapatkan perlindungan demi kepentingan terbaik anak yaitu perlindungan dari pengaruh negatif tahanan dewasa. Oleh karena itu, anak harus benar-benar dilindungi dengan adanya UU baru yaitu UU Nomor 11 Tahun 2012 tentang Sistem Peradilan Pidana Anak.

b. Asas Kelembagaan atau Pejabat pembentuk yang tepat

UU Nomor 11 Tahun 2012 Tentang Sistem Peradilan Pidana dibentuk oleh Lembaga negara atau Pejabat pembentuk peraturan perundang-undangan yang berwenang. Kewenangan Pembentukan Undang-Undang berada di tangan DPR yang bersama Presiden membahas dan menyetujui RUU. Selanjutnya, Presiden mengesahkan RUU tersebut yang telah mendapat persetujaun bersama menjadi Undang-Undang. Pembentukan Undang-Undang pada hakikatnya merupakan kekuasaan bersama antara DPR dan Presiden (Sharing Power).

c. Asas Kesesuaian antara jenis, hierarki dan materi muatan

Setiap jenis peraturan perundang-undangan dalam hierarki memiliki muatan masing-masing sesuai dengan porsinya. Materi muatan peraturan perundang-undangan harus mencerminkan asas-asas pengayoman kemanusiaan, kebangsaan, kekeluargaan, kenusantaraan bhineka tunggal ika, keadilan, kesamaan kedudukan dalam hukum dan pemerintahan, ketertiban dan kepastian hukum, keseimbangan, keserasian, dan keselarasan. Keseluruhan asas tersebut telah terakomodasi di dalam UU Nomor 11 Tahun 2012. Salah satu contoh adalah asas keadilan, tercermin dalam Pasal 3H UU Nomor 11 Tahun 2012.

d. Asas dapat dilaksanakan

UU Nomor 11 Tahun 2012 Tentang Sistem Peradilan Pidana Anak dapat dilaksanakan. Hal ini dikarenakan UU Nomor 11 Tahun 2012 tentang Sistem Peradilan Pidana Anak memang dibutuhkan oleh masyarakat untuk menjamin perlindungan terhadap Anak yang Berhadapan dengan Hukum. Kemudian tinggal apakah struktur dan kultur hukum siap untuk mengimplementasikan UU Nomor 11 Tahun 2012 Tentang Sistem Peradilan Pidana Anak tersebut atau tidak.

e. Asas Kedayagunaan dan Kehasilgunaan

UU Nomor 11 Tahun 2012 Tentang Sistem Peradilan Pidana Anak memang dibentuk karena benar-benar dibutuhkan dan bermanfaat bagi 
masyarakat. Hal ini disebabkan karena Undang-Undang terdahulu yaitu UU Nomor 3 Tahun 1997 tentang Pengadilan Anak dalam pelaksanaannya Anak belum mendapatkan Perlindungan yang semestinya. Anak diposisikan sebagai objek dan perlakuan terhadap Anak yang Berhadapan dengan Hukum cenderung merugikan anak. Selain itu, Undang-undang tersebut juga sudah tidak sesuai dengan kebutuhan hukum dalam masyarakat dan belum secara komprehensif memberikan perlindungan khusus pada Anak yang Berhadapan dengan Hukum. ${ }^{20}$

F. Asas Kejelasan Rumusan

Dalam UU Nomor 11 tahun 2012 Tentang Sistem Peradilan Pidana Anak terdapat istilah kata Restoratif Justice dan Diversi yang masih awam. Namun dalam substansi Pasal 1 angka 6 dan 7 UU Nomor 11 tahun 2012 Tentang Sistem Peradilan Pidana Anak telah memuat definisi tentang Restoratif Justice dan Diversi, agar tidak menimbulkan berbagai macam interpretasi dalam pelaksanaannya.

\section{G. Asas Keterbukaan}

Dalam pembentukan UU Nomor 11 Tahun 2012 tentang Sistem Peradilan Pidana Anak telah bersifat transparan dan terbuka.

1. Kewenangan Pembentuk Peraturan Perundang-Undangan

UU Nomor 11 Tahun 2012 Tentang Sistem Peradilan Pidana sendiri dibentuk oleh Lembaga negara atau Pejabat pembentuk peraturan perundangundangan yang berwenang. Kewenangan Pembentukan Undang-Undang berada di tangan DPR yang bersama Presiden membahas dan menyetujui RUU. Selanjutnya, Presiden mengesahkan RUU tersebut yang telah mendapat persetujuan bersama menjadi Undang-Undang.

Pembentuk Peraturan Perundang-Undangan memiliki kewenangan atas pembentukan substansi dari Peraturan Perundang-Undangan tersebut. Sama halnya dengan pembentuk UU Nomor 11 Tahun 2012 tentang Sistem Peradilan Pidana Anak memiliki kewenangan dalam membentuk substansi UU Nomor 11 Tahun 2012 tentang Sistem Peradilan Pidana Anak, dimana salah satunya Pembentuk Undang-Undang memberikan kewenangan kepada Penyidik, Penuntut

\footnotetext{
${ }^{20}$ Penjelasan atas Undang-Undang Nomor 11 Tahun 2012 Tentang Sistem Peradilan Pidana Anak
} 
Umum dan Hakim Anak untuk melakukan proses peradilan pidana terhadap Anak.

2. Jenis dan hierarki Peraturan Perundang-Undangan

Jenis dan Hierarki Peraturan Perundang-Undangan ini diatur dalam Pasal 7

UU Nomor 12 Tahun 2011 Tentang Pembentukan Peraturan PerundangUndangan. Jenis dan Hierarki Peraturan Perundang-Undangan terdiri atas $:^{21}$ (1). UUD 1945; (2). Ketetapan Majelis Permusyawaratan Rakyat; (3). UndangUndang atau Peraturan Pemerintah Pengganti Undang-Undang; (4). Peraturan Pemerintah; (5). Peraturan Presiden; (6). Peraturan Daerah Provinsi; (7).Peraturan Daerah Kabupaten atau Kota.

Kekuatan hukum Peraturan Perundang-Undangan sesuai dengan hierarki seperti tersebut diatas. Misalnya UU Nomor 11 tahun 2012 tentang sistem Peradilan Pidana Anak tidak boleh bertentangan dengan UUD 1945 karena tingkatan UUD 1945 lebih tinggi dibandingkan UU Nomor 11 tahun 2012 tentang sistem Peradilan Pidana Anak. Jika dalam UU Nomor 11 tahun 2012 tentang sistem Peradilan Pidana Anak terdapat ayat atau pasal yang bertentangan dengan UUD 1945 maka UU Nomor 11 tahun 2012 tentang sistem Peradilan Pidana Anak dapat diajukan pengujian ke Mahkamah Konstitusi. Sedangkan jika ada suatu peraturan perundang-undangan yang lebih rendah dari Undang-Undang bertentangan dengan UU Nomor 11 tahun 2012 tentang Sistem Peradilan Pidana Anak maka dapat dilakukan pengujian ke Mahkamah agung. ${ }^{22}$

3. Materi Muatan Peraturan Perundang-Undangan

Tentang Pembentukan Peraturan Perundang-Undangan. Materi muatan Peraturan Perundang-Undangan antara lain berisi sebagai berikut : ${ }^{23}$

a. Pengaturan lebih lanjut mengenai ketentuan UUD 1945.

UU Nomor 11 tahun 2012 tentang sistem Peradilan Pidana Anak adalah bertujuan untuk dapat mewujudkan Peradilan yang benar-benar menjamin

\footnotetext{
${ }^{21}$ Pasal 7 Undang-Undang Nomor 12 Tahun 2011 Tentang Pembentukan Peraturan PerundangUndangan

${ }^{22}$ Ketentuan Pasal 9 Undang-Undang Nomor 12 Tahun 2011 Tentang Pembentukan Peraturan Perundang-Undangan

${ }^{23}$ Ketentuan Pasal 10 Undang-Undang Nomor 12 Tahun 2011 Tentang Pembentukan Peraturan Perundang-Undangan
} 
perlindungan kepentingan terbaik bagi Anak yang Berhadapan dengan Hukum sebagai generasi penerus bangsa.

Kepentingan terbaik bagi anak harus benar-benar dilindungi karena ini merupakan pengaturan lebih lanjut dari ketentuan UUD 1945 Pasal 28B berikut ini

Pasal 28B ayat (2) UUD Tahun $1945 * *)$ :

Setiap anak berhak atas kelangsungan hidup, tumbuh, dan berkembang serta berhak atas perlindungan dari kekerasan dan diskriminasi. Hak tersebut adalah hak asasi manusia yang tidak dapat dikurangi dalam keadaan apapun. Kemudian dipertegas oleh Pasal 28I ayat (1) UUD RI Tahun 1945.

b. Perintah suatu Undang-Undang untuk diatur dengan Undang-Undang;

Untuk memperbaiki UU Nomor 3 Tahun 1997 Tentang Pengadilan anak, maka diperlukan pembentukan Undang-undang baru yang lebih baik yaitu dengan dibentuk dan diundangkannya UU Nomor 11 Tahun 2012 Tentang Sistem peradilan Pidana Anak.

c. Pengesahan perjanjian Internasional tertentu

UU Nomor 11 Tahun 2012 Tentang Sistem peradilan Pidana Anak juga berisikan prinsip-prinsip perlindungan anak dimana prinsip tersebut sesuai dengan ketentuan dalam Konvensi Hak Anak sebagaimana telah diratifikasi oleh Indonesia dengan Keputusan Presiden Nomor 36 Tahun 1990 tentang Pengesahan Convention on the Rights of the Child.

d. Tindak lanjut atas putusan mahkamah Konstitusi.

Misalnya Judicial Review Pasal tentang batas usia anak nakal dalam Putusan Mahkamah Konstitusi Republik Indonesia Nomor 1/PUU-VIII/2010. Kemudian tindak lanjut atas Putusan Mahkamah Konstitusi tersebut dilakukan oleh DPR atau Presiden yang berwenang dalam Pembentukan Peraturan Perundang-Undangan yaitu dengan membentuk UU Nomor 11 Tahun 2012 Tentang Sistem Peradilan Pidana Anak, dimana Pasal tentang batas usia anak dalam UU Nomor 11 Tahun 2012 Tentang Sistem Peradilan Pidana Anak sesuai dengan hasil Putusan Judicial Review tersebut.

e. Pemenuhan kebutuhan hukum dalam masyarakat.

UU Nomor 11 Tahun 2012 Tentang Sistem Peradilan Pidana Anak merupakan pemenuhan dari kebutuhan hukum dalam masyarakat. Hal ini 
dikarenakan UU Nomor 11 Tahun 2012 Tentang Sistem Peradilan Pidana Anak diyakini mampu untuk dapat mewujudkan Peradilan yang benar-benar menjamin perlindungan kepentingan terbaik bagi Anak.

\section{KESIMPULAN}

Teori Perundang-Undangan berorientasi pada mencari kejelasan dan kejernihan makna atau pengertian dan bersifat kognitif. Artinya, Teori PerundangUndangan menekankan bukan pada proses pembentukan peraturan perundangUndangan, namun menekankan pada bagaimana membentuk materi Peraturan Perundang-Undangan. Tinjauan Teori Perundang-Undangan terhadap UU Nomor 11 Tahun 2012 tentang Sistem Peradilan Pidana Anak berarti dapat diartikan meninjau dari segi :

1. Asas-asas pembentukan Peraturan Perundang-Undangan.

UU Nomor 11 Tahun 2012 tentang Sistem Peradilan Pidana Anak telah mencerminkan 7 (tujuh) asas Pembentukan Peraturan Perundang-Undangan yang baik.

2. Kewenangan Pembentuk Peraturan Perundang-Undangan.

UU Nomor 11 Tahun 2012 Tentang Sistem Peradilan Pidana Anak sendiri telah dibentuk oleh Lembaga negara atau Pejabat pembentuk peraturan perundang-undangan yang berwenang. Kewenangan Pembentukan UndangUndang berada di tangan DPR yang bersama Presiden membahas dan menyetujui RUU tersebut. Selanjutnya, Presiden mengesahkan RUU tersebut yang telah mendapat persetujuan bersama menjadi Undang-Undang.

3. Jenis dan Hierarki Peraturan Perundang-Undangan.

UU Nomor 11 Tahun 2012 Tentang Sistem Peradilan Pidana Anak tidak bertentangan dengan Peraturan Perundang-Undangan yang lebih tinggi.

4. Materi muatan Peraturan Perundang-Undangan dari Ketentuan UU Nomor 11 Tahun 2012 tentang Sistem Peradilan Pidana Anak.

UU Nomor 11 Tahun 2012 tentang Sistem Peradilan Pidana Anak telah mencerminkan 10 asas yang ada di dalam materi muatan Peraturan PerundangUndangan. 


\section{DAFTAR PUSTAKA}

Sumber Buku :

Ghufran M. 2010, Hak dan Perlindungan Anak di Atas Kertas, Jakarta: PT. Perca

Nashriana, 2012, Perlindungan Hukum Pidana Bagi Anak di Indonesia,Jakarta : PT Raja Grafindo Persada

Mulyadi, Lilik, 2005, Pengadilan Anak di Indonesia Teori, Praktik dan Permasalahannya, Bandung : Mandar Maju

Paulus Hadisuprapto, 2008, Delinkuensi Anak, Pemahaman dan Penanggulangannya, Malang : Bayumedia Publishing

Sambas, Nandang. 2010, Pembaharuan Sistem Pemidanaan Anak di Indonesia, Yogyakarta : Graha Ilmu

Samin dan Yayasan Setara, 2006, Situasi Anak yang Berkonflik dengan Hukum, Yogyakarta : Samin dan Yayasan Setara

Peraturan Perundang-Undangan :

UUD 1945

Undang-Undang Nomor 3 Tahun 1997 Tentang Pengadilan Anak

Undang-Undang Nomor 23 Tahun 2002 Tentang Perlindungan Anak

Undang-Undang Nomor 12 Tahun 2011 Tentang Pembentukan Peraturan Perundang-Undangan

Undang-Undang Nomor 11 Tahun 2012 Tentang Sistem Peradilan Pidana Anak

Putusan Mahkamah Konstitusi Republik Indonesia Nomor 1/PUU-VIII/2010

Sumber lain :

Materi Workshop tentang "Kedudukan Hukum atau Kebijakan di bawah Peraturan Menteri Perencanaan Pembangunan Nasional atau Kepala bapennas" oleh Arief Christiono Soebroto, SH., Msi selaku Direktur Analisa Peraturan Perundang-Undangan Bappenas 